\title{
Controlling Avoidance of Food Safety Regulations in Meat Packing Industry
}

\author{
Dragan Miljkovic ${ }^{1}$, Dane Braun ${ }^{2}$ \\ ${ }^{1}$ Department of Agribusiness \& Applied Economics, North Dakota State University, Fargo, USA \\ ${ }^{2}$ Department of Agriculture, State of North Dakota, Bismarck, USA \\ Email: Danebraun@nd.gov, Dragan.Miljkovic@ndsu.edu
}

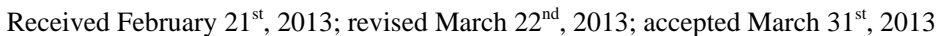

\begin{abstract}
Copyright () 2013 Dragan Miljkovic, Dane Braun. This is an open access article distributed under the Creative Commons Attribution License, which permits unrestricted use, distribution, and reproduction in any medium, provided the original work is properly cited.
\end{abstract}

\begin{abstract}
The sale of meat and poultry contains asymmetric information dealing with food safety. Since pathogens in most cases are invisible, consumers lack information on the safety of meat and poultry. Government interaction through the Food Safety and Inspection Service (FSIS) in the meat and poultry industry is necessary to regulate the safety of meat and poultry products. Inevitably, any rules in society are likely to include violators. The cost of perfectly safe food is far too great for the industry to bear. The marginal gain in revenue from violating a regulation may be greater than the marginal cost. Violators of rules may resort to sophisticated means to avoid detection of the original violations. The means used to avoid detection may be legal or illegal. Effective regulation of avoidance activities will lead to lower violations of the original crime. Such regulations may be ex-ante or ex-post. This paper discusses potential effectiveness of ex-ante or ex-post regulations on avoidance activities of food safety regulations in the meat and poultry industry. The use of ex-ante measures such as contracting external service providers coupled with the threat of ex-post punishment on service providers would potentially decrease the number of avoidance activities and their associated original crime in the meat and poultry industry.
\end{abstract}

Keywords: Food Safety; Regulation; Avoidance Control; US Meat Packing Industry

\section{Introduction}

In general, the sale of meat and poultry contains asymmetric information dealing with safety. Asymmetric information is a characteristic of many business situations in which a producer or a seller of a product knows more about its quality than the buyer does (Pindyck \& Rubinfeld, 1992). Since pathogens in most cases are invisible, consumers lack information on the safety of meat and poultry. Government interaction through the Food Safety and Inspection Service (FSIS) in the meat and poultry industry is necessary to regulate the safety of meat and poultry products. Inevitably, any rules in society are likely to include violators. In the meat and poultry industry, violators of the regulations may see economic benefit to do so. The cost of perfectly safe food is far too great for the industry to bear. The marginal gain in revenue from violating a regulation may be greater than the marginal cost. Violators of rules may resort to sophisticated means to avoid detection of the original violations. The means used to avoid detection may be legal or illegal in and of themselves. Effective regulation of avoidance activities will lead to lower violations of the original crime. Such regulations may be ex-ante or ex-post. The paper will examine potential effectiveness of ex-ante or ex-post regulations on avoidance activities of food safety regulations in the meat and poultry industry.

\section{History of FSIS}

The beginning of federal inspection in the meat and poultry industry stems from the development of the United States Department of Agriculture (USDA) in 1862. The expansion of the railroad, along with the development of refrigeration, enabled packers to process year round and ship farther distances. The Bureau of Animal Industry (BAI) was created in 1884 to prevent diseased animals from making their way in to human food (USDA, 2007). Upton Sinclair published a book titled "The Jungle" (Sinclair, 1906), which exposed the unsanitary conditions at meat packinghouses in Chicago in the early 20th century. The book pressured congress and then president, Theodore Roosevelt, to pass both the Food and Drug Act along with the Meat Inspection Act. Both acts were passed in 1906 (USDA, 2007). BAI's inspection responsibilities grew immensely after the passing of the Meat Inspection Act. In 1953, the BAI's responsibilities were transferred to the newly created Agriculture Research Service (ARS) and BAI was terminated (USDA, 2007). The Poultry Products Inspection Act was passed in 1957 after an enormous jump in demand for poultry products post World War II. The growing meat packing industry became difficult to regulate and by 1967 the Federal Meat Inspection Act was amended as the Wholesome Meat Act (USDA, 2007). The Whlesome Meat Act increased the individual stateinspection responsibilities. The Poultry Products Inspection Act followed suit in 1968 and was amended under the original name. During the late 1960's both the meat and the poultryinspection programs were combined into the Consumer and Marketing Service of USDA's Agricultural Research Service. The Animal 
and Plant Health Service created in 1971, latter named the Animal and Plant Health Inspection Service (APHIS), became responsible for meat and poultry inspection (USDA, 2007). The inspection responsibilities changed hands once again in 1977, when the Food Safety and Quality Service division was created. The division changed their name one last time in 1981 to the Food Safety and Inspection Service (FSIS). Currently the FSIS is responsible for the inspection of meat and poultry during slaughter and processing in the United States. Some states take responsibility for inspection of plants but they use the same standards, or greater, than the FSIS (USDA, 2007). The FSIS, more specifically, is responsible for inspecting meat and poultry from the time it enters the slaughterhouse to the time it reaches the retail level. Inspectors at a slaughterhouse will examine every animal before (ante mortem) and after death (post mortem) looking for signs of disease. The inspector is also responsible for monitoring sanitation and pathogen levels, along with verifying proper labeling and recordkeeping. With respect to meat and poultry processing plants, the USDA inspectors are not required to inspect every item on the production line. Per product inspection, is less at processing plants since their input of meat or poultry has already been inspected and passed. The inspectors are responsible for monitoring sanitation levels, product ingredients, and recordkeeping along with random testing of products. Processing plants may be inspected daily. However, the USDA does not disclose how often inspectors visit the facilities. USDA inspectors check both slaughter and processing plants records to verify their compliance. FSIS is also responsible for inspecting meat and poultry during storage and transportation, where they inspect for proper product handling procedures along with sanitation levels. USDA inspectors may use a variety of enforcement tools to keep adulterated product from reaching consumers. The inspector may halt operation by refusing to perform inspection until the problem is fixed. The FSIS can seize adulterated or contaminated products on the processing line. The FSIS's power is limited, because they are unable to recall meat after it has left the plant and entered the retail market. Recalls in the US are in most cases voluntary by the company. The FSIS may refer the case to a federal attorney in serious cases (Rawson, 2003).

Meat and poultry products sold as adulterated, mislabeled, or misbranded can be produced at a lower cost and in turn be sold at a lower price compared to safe food. Consumers suffer the consequences of the unwholesome food. According to the Federal Meat Inspection Act, title 21, chapter 12, subchapter 1, no official USDA device, mark, label, or certificate can be forged. No business can knowingly label their product as inspected and passed when in fact, the product has not been inspected or the product was inspected and condemned. The act defines misbranded as any label containing misleading information, fails to mention all ingredients in the product, or if the product fails to bear the official inspection legend. Labels must be positioned on the outermost package layer and visible to consumers. An official inspection legend is any symbol that represents the product as being inspected and passed by the USDA. The sale of adulterated and uninspected meat and poultry benefits the violators and is harmful to consumers. The FSIS detains every year millions of pounds of uninspected and/or adulterated meat and poultry (see the following website for the current and archived recall and detention cases: http://www.fsis.usda.gov/
Fsis_Recalls/index.asp). For instance, only in 2005 there were more than 600 detention cases totaling almost 83 million of pounds of uninspected or adulterated meat.

\section{Meat Packing Industry}

The meat packing industry consists of three main types of plants: poultry processing, animal (except poultry) slaughtering, and meat (except poultry) processing. Poultry processing plants includes all slaughter houses and processors. In 2002, there were 536 poultry processing plants, which were owned by 311 companies. Of the total 536 poultry processing plants, there were $50 \%$ (268) of plants operating with 250 or more employees. The same 250 or more employee plants contributed $91 \%$ of the total value of shipments for 2002. In 2002 there were 1870 animals (except poultry) slaughtering plants, which were owned by 1776 companies. Six percent or 113 of animal (except poultry) slaughtering plants had 250 or more employees and contributed $88 \%$ of the total value of shipments. Meat processing plants usually engage in assembly, packing, and cooking of meat (except poultry) products. As of 2002 there were 1338 meat-processing plants owned by 1193 companies. Nine percent or 121 of meat-processing plants had 250 or more employees and contributed $56 \%$ of the total value of shipments. (US Census Bureau) In both the poultry processing and animal (except poultry) slaughter plants, the larger less numerous plants produced the majority of the products sold. Economies of scale come into effect to generate lower costs and higher profits per pound. This fact is further exacerbated especially in the animal slaughter plants with their total number decreasing by almost 15 percent between 2002 and 2007 suggesting that many small plants could not survive the competition with economically more efficient large-scale plants. The exception to this trend is the meat processing sector where small plants still hold a good portion of the total production as seen in the Tables 1 and 2 .

\section{Food Safety Regulations-PR/HACCP}

An outbreak of E. coli O157:H7 infections in 1993, which left 400 ill and four dead, led to the demand for stricter standards in the meat packing industry. Officials insisted inspection should become more "science based" compared to past inspections where only sight, touch, and smell were used. FSIS introduced a proposal on February 3, 1995, to satisfy the demand for stricter standards called the Pathogen Reduction and Hazard Analysis Critical Control Points (PR/HACCP). After many comments and a review of the proposal, the final rule was introduced on July 25, 1996. The PR/HACCP final rule included seven principles plants needed to follow during their transition: 1) hazard analysis, 2) critical control point identification, 3) establishment of critical limits, 4) monitoring procedures, 5) corrective actions, 6) recordkeeping, and 7) verification procedures. Critical control points of food safety are found and plans are developed to reduce and prevent contamination. The plant monitors the critical control points for contamination, and when a contaminated product is found they locate and fix the source of the problem. Along with implementing the HACCP, the plants are required to randomly test for general $E$. coli in their production. Generic E. coli is found in the digestive tract of cattle and the testing ensures there is no fecal matter on meat or 
Table 1.

The number and the size of plants in the meat and poultry processing industry.

\begin{tabular}{|c|c|c|c|c|}
\hline & Plants & Companies & $\begin{array}{l}250+\text { Employee } \\
\text { Establishments }\end{array}$ & $\begin{array}{c}250+\text { Employee } \\
\text { Establishments } \\
\text { Percent of Total }\end{array}$ \\
\hline \multicolumn{5}{|l|}{ Poultry Processing } \\
\hline 1997 & 473 & 257 & & \\
\hline 2002 & 536 & 311 & 268 & $50 \%$ \\
\hline 2007 & 557 & 324 & & \\
\hline \multicolumn{5}{|c|}{ Animal (Except Poultry) Slaughter } \\
\hline 1997 & 1391 & 1307 & & \\
\hline 2002 & 1870 & 1776 & 113 & $6 \%$ \\
\hline 2007 & 1603 & 1523 & & \\
\hline \multicolumn{5}{|c|}{ Meat (Except Poultry) Processing } \\
\hline 1997 & 1295 & 1163 & & \\
\hline 2002 & 1338 & 1193 & 121 & $9 \%$ \\
\hline 2007 & 1381 & 1237 & & \\
\hline
\end{tabular}

Note: US Census Bureau, 2002, 2007.

Table 2.

The value of shipments in the meat and poultry processing industry.

\begin{tabular}{cccc}
\hline 2002 & $\begin{array}{c}\text { Total Value of } \\
\text { Shipments }\end{array}$ & $\begin{array}{c}\text { 250+ Employees Establishment } \\
\text { Value of Shipments }\end{array}$ & $\begin{array}{c}\text { Percent Value of } \\
\text { Shipments for 250+ }\end{array}$ \\
\hline $\begin{array}{c}\text { Poultry Processing } \\
\text { Animal (Except } \\
\begin{array}{c}\text { Poultry) Slaughter } \\
\text { Meat (Except Poultry) }\end{array}\end{array}$ & $\$ 37634609000.00$ & $\$ 34309124000.00$ & $91 \%$ \\
Processing & $\$ 56481035000.00$ & $\$ 49430081000.00$ & $88 \%$ \\
\hline
\end{tabular}

Note: US Census Bureau, 2002.

poultry. The results of the microbial testing are being used to verify the HACCP plan is working effectively. FSIS also conducts random tests for Salmonella during production and at the retail level. Salmonella was chosen to verify that the PR/ HACCP plan is working effectively because it is one of the leading causes of food borne illnesses. Plants also need to implement Sanitation Standard Operating Procedures (SSOP), where plants develop procedures to maintain proper sanitation. SSOP records stating when procedures are completed and when corrective action has taken place must be kept. Recordkeeping is used to help inspectors verify the PR/HACCP regulations are being followed (USDA, 1996). Dates of compliance are determined by the size of the plant. Plants with 500 or more employees had a compliance deadline of January 1998. Small plants with the number of employees ranging from 10 to 499 had to comply by January 1999, and very small plants with less than ten employees or less than \$2.5 million in annual sales had a deadline of January 2000. The latter deadline for small plants was made out of fairness, since small plants may incur higher costs per pound to implement the PR/HACCP plan compared to large plants (Muth et al., 2007).

The PR/HACCP regulation consists of two different food safety standards. The E. coli and Salmonella testing are considered performance standards in which a plant can use any means to reach the standards. Performance standards tend to be less costly compared to process standards in which the process of producing a product is regulated. Sanitation Standard Operating Procedures (SSOP) and HACCP plans are considered process standards. Process standards tend to be less efficient at achieving proper food safety because of unnecessary steps they may add to the process. With performance standards, a plant can use any means to achieve the standard, which is usually the most cost effective method (Ollinger et al., 2004).

\section{Cost and Benefits of Compliance}

The PR/HACCP rule has been the center of numerous studies, which analyze the costs and benefits of the regulation (e.g., Antle, 2000; Muth et al., 2002; Nganje \& Mazzocco, 2000). The actual number of foodborne illnesses is difficult to achieve since most cases are not reported or are misreported as a different illness. Also, the effect of offsetting behavior can skew the cost and benefit results of a regulation. Many safety and health policies are adopted to reduce harm to potential victims from accidents and other harmful events. Decreased care by potential victims in response to the implemented policies is what has been termed offsetting behavior (OB) (Miljkovic, Nganje, \& Onyango, 2009). Economists have (Peltzman, 1975; Hause, 2006) recognized attenuation and sometimes even reversal of the direct policy effect on expected harm may occur 
because of $\mathrm{OB}$ by potential victims as the victims reduce their level of care in response to the policy. When policy makers ignore $\mathrm{OB}$, where it is significant, the predicted policy effect will be overstated. An example of offsetting behavior is noticeable when a consumer believes the meat or poultry product they purchased is safer because of the regulations, and the consumer may not cook it as thoroughly. This increases the likelihood of getting infected with some pathogen bacteria found in meats. Nganje et al. (2007) show how offsetting behavior plays a role in the increasing gap between decreasing pathogen levels in processing plants and the frequency of food borne illness reported in the US. Ollinger et al. (2004) conducted a survey which included some benefits of the PR/HACCP regulation and one of them was product shelf life. Of the plants that were surveyed and responded, 9\% reported their products shelf life increased by more than one week, $21 \%$ reported an increase in product shelf life by less than one week, $1 \%$ reported a decrease in shelf life, and rest of the plants reported their product shelf life as unchanged. The increase in shelf life is believed to be from the decrease in bacteria and pathogens that spoil the meat or poultry product (Ollinger et al., 2004).

As seen before, the meat and poultry industry consists of very few large plants, which process most of the products sold. This is evidence of economies of scale and can be carried over into the cost of compliance for the PR/HACCP regulation. The introduction of the PR/HACCP rule did not require any capital investments; however, plants not up to FSIS standards may have needed to invest in capital and/or labor. According to Table 3, summarizing the cost of compliance, the average variable cost per pound of slaughtered meat ranged from approximately 1.5 cents to 2.5 cents for cattle and hogs. Variable costs of compliance for hog and cattle slaughterhouses are approximately 3 times larger for the smaller ( 0 - 19 percentile) plants compared to the larger (80 - 99 percentile) plants. Fixed costs of compliance for hog and cattle slaughterhouses are over 6 times larger for smaller plants compared to larger plants. Economies of scale allow larger plants to spread the costs of labor and capital investments over a greater amount of product reducing the per pound cost of compliance. In each specific meat industry, the large processors had less cost per pound compared to small processors. The unweighted average finds the meat cost per pound of all plants in a percentile range while the weighted average gives weights to the individual plants using their amount of output (Ollinger et al., 2004).

Small plants are unable to bear the cost of the labor and capital investments needed to meet the PR/HACCP standards and satisfy their customers. Plants may not have needed capital investments if they were already operating at FSIS standards. (Ollinger \& Moore, 2008) Numerous small plants produce a wide range of specialty products in which each product needs a PR/HACCP plan. The development of each PR/HACCP planincreases cost per pound for meat processing plants. There cordkeeping needed with each PR/HACCP plan also increases the cost for small plants. Small plants that produce commodity

Table 3.

The cost of compliance.

\begin{tabular}{|c|c|c|c|c|c|c|}
\hline \multirow{3}{*}{ Plant Type } & \multicolumn{3}{|c|}{ Unwelghted Mean Cost Per Pound ${ }^{2}$} & \multicolumn{3}{|c|}{ Industry Welghted Mean Cost Per Pound ${ }^{3}$} \\
\hline & \multicolumn{3}{|c|}{ Size Percentile } & \multicolumn{3}{|c|}{ Size Percentile } \\
\hline & $0-19$ & $80-99$ & Mean & $0-19$ & $80-99$ & Mean \\
\hline & \multicolumn{6}{|c|}{ Dollars per pound } \\
\hline \multicolumn{7}{|l|}{ Cattle Slaughter: } \\
\hline Variable Costs & 0.023 & 0.008 & 0.022 & 0.010 & 0.003 & 0.0033 \\
\hline Fixed Costs & 0.055 & 0.009 & 0.022 & 0.020 & 0.004 & 0.0045 \\
\hline Number of Plants & 17 & 27 & 135 & 17 & 27 & 135 \\
\hline \multicolumn{7}{|l|}{ Hog Slaughter: } \\
\hline Variable Costs & 0.016 & 0.05 & 0.014 & 0.008 & 0.001 & 0.0020 \\
\hline Fixed Costs & 0.050 & 0.008 & 0.026 & 0.022 & 0.003 & 0.0043 \\
\hline Number of Plants & 23 & 22 & 96 & 17 & 22 & 96 \\
\hline \multicolumn{7}{|l|}{ Poultry Slaughter: } \\
\hline Variable & 0.025 & 0.004 & 0.010 & 0.023 & 0.004 & 0.0037 \\
\hline Fixed Costs & 03013 & 03004 & 03008 & 03012 & 03003 & 03047 \\
\hline Number of Plants & 14 & 9 & 58 & 14 & 11 & 58 \\
\hline \multicolumn{7}{|c|}{ Cooked Meat Processing/No Slaughrer ${ }^{4}$ : } \\
\hline Variable Costs & 0.018 & 0.005 & 0.016 & 0.015 & 0.005 & 0.007 \\
\hline Fixed Costs & 0.019 & 0.019 & 0.036 & 0.057 & 0.015 & 0.018 \\
\hline Number of Plants & 50 & 37 & 198 & 50 & 37 & 198 \\
\hline \multicolumn{7}{|c|}{ Raw Meat Processing/No Slaughter ${ }^{5}$ : } \\
\hline Variable Costs & 0.020 & 0.005 & 0.013 & 0.006 & 0.003 & 0.0046 \\
\hline Fixed Costs & 0.027 & 0.012 & 0.017 & 0.006 & 0.005 & 0.0080 \\
\hline Number of Plants & 25 & 26 & 139 & 25 & 26 & 139 \\
\hline
\end{tabular}

Note: “Meat and Poultry Plants’ Food Safety Investments: Survey Findings” by Michael Ollinger, Danna Moore, and Ram Chandran (2004). 
products are unable to compete against the large processing plants and are faced to specialize or exit the industry. The development of the PR/HACCP regulations in 1996 also increased production downtime and decreased production yield throughout the industry. During regular daytime hours, the actual cost of inspection is free; however, cost of compliance may be far too great for some plants to manage.

The implementation of a regulation to better food safety may cause a variety of effects on different plants. For example, Muth et al. (2007) discovered that very small and small slaughter plants of any kind were more likely to exit because of the PR/HACCP regulation. The effectiveness of a food safety regulation needs to be measured by both their benefits and costs. There are numerous differences in slaughter plants and these cause different exit rates and regulation effects. These differences are evident when examining exit rates: older meat slaughter plants are more likely to exit than younger plants; plants in states with higher minimum wages are less likely to exit; and meat slaughter plants that slaughter cattle, along with poultry slaughter plants that slaughter turkeys, are less likely to exit.

Muth et al. (2007) analyzed the rates of entry and exit, before, during, and after the implementation of the PR/HACCP regulation. The adoption of the PR/HACCP may have caused small and very small meat slaughter plants to exit. According to the results, very small meat slaughter plants were $11.1 \%$ more likely to exit during the implementation period compared to before implementation of the PR/HACCP regulation. Small meat slaughter plants were also more likely to exit during the implementation period by $8.4 \%$. When comparing the period after implementation of the regulation to before implementation, very small meat slaughter plants were $6.6 \%$ and small meat slaughter plants were $7.3 \%$ more likely to exit. After reviewing the results, the authors suggested that very small and small meat slaughter plants were more likely to exit because of the PR/HACCP regulations. The authors also suggested that the exit rate because of the PR/HACCP regulations decreases with time. Large meat slaughter plants likelihood of exiting did not change during and after implementation compared to before the PR/HACCP regulation. When reviewing the data for poultry slaughter plants, very small and small plants were no more likely to exit during implementation compared to before implementation of the PR/HACCP regulation. However, very small poultry slaughter plants were $11.1 \%$ and small poultry slaughter plants were $8 \%$ more likely to exit after implementation of the regulation compared to before implementation. Large poultry slaughter plants likelihood to exit did not change because of the PR/HACCP regulation. Very small and small poultry slaughter plants exited the industry latter compared to their meat slaughter plant counterparts. The results suggest very small and small meat slaughter plants were more likely to exit because of the PR/HACCP regulation but the rate decreased over time. The decrease in rate could be caused by the exit of inefficient plants in the beginning leaving the more efficient plants to survive.

The cost of compliance depended on many variables. For example, plants which had contracts that included food safety standards, produced products under brand names, or exported their product to countries who then inspect their product, were subject to a lower fixed cost of compliance for the PR/HACCP regulation. The plants experienced lower costs because they were achieving higher food safety standards before the implementation of the PR/HACCP regulation compared to other plants. The survey also found plants that utilized a process control program before implementation of the regulation had less or the same costs compared to other plants. Process control programs consist of monitoring critical control points similar to the PR/HACCP plan (Ollinger et al., 2004).

In addition to the cost of compliance, there is a loss of possible revenue for rejected meat or poultry. The loss of revenue is an opportunity cost for the plant. When a plant incurs a noncompliance issue, they must dispose of their contaminated product, which is accompanied by a cost to the plant. The disposal of their input is an opportunity cost, since they cannot use that particular input to produce a desirable output. In general, contaminated meat or poultry is used in other non-food products; however, their value decreases substantially with the contamination (Cho \& Hooker, 2004).

\section{Violations}

The loss of sales along with the cost of compliance compels some businesses to participate in illegal activities. Violating a regulation may be costly if caught; however, the violation may also increase a plant's profit substantially. When a plant violates a regulation, they are able to produce items at lower cost. The plant has less opportunity cost, since they do not need to dispose the defective products or inputs. If a plant is risk neutral, they will violate the regulations up to the point where marginal cost equals marginal revenue. In addition to violating the first regulation, businesses will naturally participate in other illegal acts to avoid detection. The act of committing an avoidance behavior may be a crime in itself; such acts in the meat industry include mislabeling, counterfeiting official inspection documents, illegal record keeping, or mail fraud, etc. Other acts of avoidance, such as the use of sophisticated means to prevent detection, may not be a crime by themselves, but their use may increase the punishment for the original crime (Nussim \& Tubbach, 2008). A couple of cases serve as examples to illustrate the ex-post punishment of the violators.

\section{Sale of Uninspected Meat}

The sale of uninspected meat and poultry is in violation of the Federal Meat Inspection Act and businesses may perform other illegal activities to reduce their risk of detection. Such avoidance activities include mislabeling, misbranding, mail fraud, and/or illegal record keeping. In the case of the Queen's Market grocery store from Kansas City, MO, along with the Kingsville Hog Market, the avoidance was mislabeling their meat as passing USDA inspection and the initial violation was the sale of uninspected meat. Kingsville Hog Market delivered the swine to Parmley's Holden locker, a USDA non-inspected facility, where it was slaughtered and processed. Queen's Market knowingly purchased the uninspected meat and sold it as USDA inspected meat. In total 9057 pounds of swine product was offered for sale or sold to customers between November 29, 2002 and March 6, 2003. Kim Huynh, Nham Pham, and their business Queen's Market along with Rick Anstine, owner of Anstine Enterprises and Kingsville Hog Market were sentenced on December 6, 2007. According to John F. Wood, United States Attorney for the Western District of Missouri, "The court ordered Queen’s Market to pay a \$2000 fine following its guilty plea to aiding and abetting the sale to the public of adulterated food that was unfit for human consumption. Anstine, Huynh and Pham were each sentenced to one year of probation after 
pleading guilty to aiding and abetting the misbranding of food. On Aug. 7, 2007, the court also ordered Anstine Enterprises to pay a $\$ 10,000$ fine after pleading guilty to aiding and Abetting the misbranding of food" (http://www.usdoj.gov/us0ao/mow/news-2007/anstine.sen.htm). Selling uninspected meat is harmful to consumers and socially wasteful. The effective use of ex-ante and/or ex-post regulations on avoidance activities may lower the probability of the occurrence of such an act.

\section{Sale of Adulterated Meat}

In general, the inspection of wholesale, storage, and transportation businesses in the meat industry is lower than slaughterhouses and processing plants. Substantial amounts of crimes committed in the meat industry occur in the meat-handling sector. One of the most common crimes committed is the sale or transportation of adulterated meat or poultry. Adulterated meat or poultry is defined using such terms as unhealthy, unwholesome, inedible, or filthy, etc. Meat or poultry can become adulterated when stored, transported, or processed in unsanitary conditions. A misdemeanor is charged to the company and/or individual who unknowingly sold or transported the adulterated product. The punishment of this crime may increase to a felony, if the violator knowingly sold or transported the adulterated product. When a violator of this crime intends to defraud customers and/or the government, the punishment for such an act increases. The intent to defraud can be interpreted as an avoidance activity, which may or may not be a crime in itself (Food Processing, 2002).

When a business recognizes their meat or poultry products have become adulterated they may decide to continue operations as normal and knowingly sell the adulterated meat or poultry to their customers. The act of knowingly selling adulterated meat or poultry is the original crime committed. To avoid detection, the violator may participate in other legal or illegal activities. The decision to sell the adulterated meat depends on the cost of disposing of the product, which includes the potential loss of sales also known as opportunity cost. If the costs are far too great, then the decision to participate in illegal activities may become more economical for the business. The decision to sell adulterated meat also depends on several factors such as what kind of risk taker the business is along with the amount of punishment incurred for detection. The business in either case may or may not fix the source of the adulterated meat.

In the case of LaGrou distribution systems, the crime was the sale of adulterated meat and using multiple avoidance activities to prevent detection. LaGrou distribution systems operated a cold storage warehouse in Chicago. The warehouse stored both meat and poultry products for their customers. On occasion, the total amount of product coming in and going out in a day would reach two million pounds. Along with storing meat and poultry products, the warehouse was a perfect habitat for rodents. The rodents created unsanitary conditions at the warehouse, which allowed meat and poultry products to become adulterated. The beginning of the rodent problem is unknown, but the company knew about the problem since 1999, based off the testimony by their manager David Smith. Smith found the problem soon after he began working in January of 1999, and he promptly told LaGrou president, Jack Stewart. Stewart and Smith would have frequent meetings about the rodent problem, approximately three times a week. The rodent problem only worsened over time according to Smith's testimony. According to Smith by late 2001 or early 2002, employees were catching at least one or two rats a day. LaGrou employees would destroy products in which the rodent damage was visible by the naked eye. However, LaGrou did not conduct any tests to ensure other products were not adulterated. As the problem worsened, employees were instructed to participate in so-called "Rat Patrols", where at one point 50 rats were captured. These patrols were not effective in controlling the rodent problem, and LaGrou's pest control company recommended steps to alleviate the problem. The steps recommended were to: cement holes in the walls, seal sewer lids, and rodent proof their doors. Stewart believed the costs were too great and he never gave Smith the authority to follow through with the recommendations. On many occasions, customers would make claims for damaged product. On one occasion a customer made a claim that their product was damaged by rodents. After hearing the claim, Stewart sent them a letter stating they have a small rodent problem in their basement freezer and that the customer's product would be moved. The customer's product was never moved, and the rodent problem was not isolated to one area. LaGrou did note product damage on customer's bills, however they would never report it as rodent damage. They would use such terms as damaged by the forklift etc. instead. In the spring of 2001, a quality assurance manager for a LaGrou customer, Aura Foods, came to inspect their product. The manger found a severe rodent problem, along with mold, ceiling and wall damage, and other unsanitary conditions. When the problem was brought to the attention of Stewart through a claim of product damage by Aurora Food, he quickly downplayed the situation. Stewart refused to pay the claim and lied to Aurora Foods, by stating a recent American Sanitation Institute inspection found no problems, and their pest control company only found "two totes with old mouse droppings". Testimony by both the pest control company and the American Sanitation institute reinforced the claim that there was a severe rodent problem. On May 25, 2002, a USDA inspector visited the facility and found employees processing ham to be frozen without proper USDA inspection. A return visit by another inspector on May 29, 2002, yielded a detention of the ham after examining the unsanitary conditions the ham was being processed and stored. That same day both inspectors examined the warehouse more thoroughly. The inspectors found adulterated meat products, fresh rodent droppings, along with many other sanitation violations. The inspectors told Smith they would return the next day to inspect the entire facility and that no product should enter or leave the downstairs freezer of the warehouse. With the knowledge of inspectors returning the next day, Stewart told LaGrou employees to clean up the warehouse and remove damaged product. A total of fourteen USDA inspectors, along with inspectors from other agencies, such as the FDA, arrived at the facility the following morning. The damaged product was found by inspectors in dumpsters. Samples of the products were tested and were found to be contaminated with rodent hair and fecal matter. The food product stored at LaGrou was adulterated by rodents and other unsanitary conditions. All the food products stored at the facility, a total of 22 million pounds, were detained on May 30, 2002. The detained products were either destroyed or decontaminated. Customers of LaGrou along with the USDA were able to develop a decontamination system to save over 12 million pounds of product. The cost of decontaminating was $\$ 2.7$ million. LaGrou was ordered to pay restitution to their 
customers in the amount of $\$ 8.2$ million (\$2.7 million for decontamination and $\$ 5.5$ million for destroyed product). The company was convicted with knowingly storing meat and poultry products in unsanitary conditions. A \$2 million fine was imposed on LaGrou along with a 5-year probation. Jack Stewart was convicted of five felonies and sentenced to pay part of the $\$ 8.2$ million in restitution and 33 months of prison (United States of America vs. LaGrou Distribution Systems, Incorporated).

\section{Avoidance Control}

Detection of the avoidance activity and the original crime are correlated. Generally, when a crime is detected the underlying avoidance activities are also detected. Avoidance activity can be controlled using either price or quantity methods. When using price control, the avoidance activity becomes more costly and decreases the likelihood of the business participating in the original crime. Decreasing the benefit from an avoidance activity is also considered price control. Price control may use taxes to increase the cost of an avoidance activity. In the meat industry, the benefit and or cost of avoidance activity may be changed to limit the occurrence of crimes such as the sale of adulterated meat and the sale of uninspected meat. Quantity control reduces the occurrence of avoidance activity by limiting the use of an activity. Requiring licensing for label makers in the meat industry may reduce the occurrence of a business mislabeling their product. Another example of quantity control would be prohibiting or limiting the sale and possession of avoidance devices (Nussim \& Tubbach, 2008).

Two other options of avoidance control include ex-ante regulations, and ex-post punishment. Both options can be used with price or quantity control. However, price control tends to be used with ex-post punishment and quantity control tends to be used with ex-ante regulations. Ex-post punishment is used after the avoidance activity has been detected, while ex-ante regulations are used to prevent the avoidance activity. With the avoidance activity such as mislabeling, an ex-ante regulation could be additional labeling and record keeping requirements of businesses, set forth by the USDA. Ex-post punishment may increase crime because it increases the marginal cost and marginal revenue of committing the crime. Ex-ante regulations, however, increases the cost of avoidance decreasing the likelihood of a business participating in avoidance activities and the original crimes. Control of avoidance before detection using ex-ante measures is difficult, since the regulations may hit the wrong target and have no affect on the original crime. Ex-ante regulations may also be targeted at activities that are legal when used properly which can affect non-violators of the crime. Ex-ante quantity control regulations are hard to implement in cases where detection is necessary (Nussim \& Tubbach, 2008).

Private action and government regulations both contribute to food safety. When a business increases their food safety to satisfy their customers, it is called private action. Contracts between the meat or poultry processor and their customer may include limits on pathogens and sanitation control. The meat and poultry processor benefits from higher prices and a guaranteed buyer, when they adhere to the contract's safety requirements. The customer yields benefits from the contract since there is greater control of food safety and less recalls or opportunity cost. Branding of products is also included in private action. When a product is branded, a consumer can recognize the product and its history. The consumer may determine the branded product is unsafe because of recent recalls and not purchase the product. Along with the potential loss of sales with branding, there are also benefits for the meat or poultry processor. If meat or poultry processor is able to produce safe food without recalls, than they may charge a premium for their product. The most effective and efficient method of controlling food safety processes are a variety of government regulations and private actions that include all food safety concerns. An increase in FSIS product testing along with reporting their findings to the public would help increase private action and food safety. Reporting PR/HACCP and SSOP compliance inspections to consumers will increase the demand for safe food and in turn private action in the meat industry (Ollinger \& Moore, 2008). When consumers are effectively informed on the food safety of the products than an efficient degree of food safety is attainable (Antle, 1996).

\section{Avoidance Control through Service Providers}

Control of pests such as rodents, insects, and birds are crucial in the effort to produce safe meat and poultry for consumers. Cockroaches are one of the common pests found in processing plants (Keener, 2007). Cockroaches harbor bacteria such as salmonella, which can have a harmful effect to humans. To control cockroaches their habitat must be removed, there must be inspection of incoming shipments, and possible use of a food plant permitted insecticides. Houseflies are another potential pest that can contaminate meat or poultry (Keener, 2007). Control of houseflies can be done by removing breeding sites, preventing entry of flies into the plant, and the use of flytraps. Birds, such as pigeons, sparrows, and starlings are the most common when it comes to food contamination in plants (Keener, 2007). Birds carry diseases and can contaminate meat or poultry products with their feathers, parasites such as mites, and their droppings. Preventing the birds from entering the plant is one method of control along with traps and poisons. Eliminating nesting places for birds is also an effective technique to prevent bird-food contamination. Rats and mice are also a problem in the food industry. Rodents can contaminate products by the disease they carry, and can damage product physically by gnawing, etc. Eliminating the rodent's habitat and food source is one example of control. The proper use of traps and other devices can be effective in controlling the number of rodents (Keener, 2007).

In the case of LaGrou Distribution Systems, they found no need to control the overwhelming population of rodents. The company deemed proper control of the rodents by a pest control company would be too costly. The ignorance of the company on the seriousness of the problem inevitably brought it to the attention of inspectors, and the company was punished by a substantial fine. Inspectors however were unable to recognize the problem until a numerous amount of product was sold adulterated. A proper use of an ex-ante measure to control avoidance activity would prevent the sale of adulterated meat like in the case of LaGrou Distribution System.

Nussim and Tubbach (2008) explain an ex-ante measure to control avoidance activity could be increasing the liability to service providers such as accountants, lawyers, and financial advisors who contribute to the avoidance activity. The increase 
in liability to service providers will increase the price of their service, which will increase the cost to the principle violator of the crime. The avoidance activity invested by service providers for their own benefit is assumed nonexistent or unrelated to the principle crime.

An effective control method of the sale of adulterated meat would be to eliminate avoidance activity through pest control companies. Pest control companies are considered a service provider and the use of Nussim and Tubbach (2008) ex-ante measures can be adopted. Contracts between meat or poultry processors and pest control companies are necessary to eliminate products being sold that are contaminated by pests. The contracts would have to be forced onto the processors; otherwise, they may not find it economical to comply. The relationship between the processor and their pest control company must be transparent. Actions taken by the pest control company must be well documented and accessible to inspectors. The contracts are developed so that the pest control companies become liable for the work they have done at the processor's facility. The pest control company is forced to control all pests at the processing facility because of the potential fine to them if the meat or poultry is found adulterated. Two situations are plausible with the case of a contract between processors and pest control companies: 1) The pest control company controls all pests and inspectors find no serious contamination of product. The pest control company pays no fine and generates revenue from their services. Meat and poultry processors only have to pay for the services of the pest control company according to their contract. 2) The pest control company is unable to control all pests and product becomes adulterated. Inspectors at the meat or poultry processing plant notice the pests and charge the plant with the sale of adulterated meat. The pest control company is liable for the sale of adulterated meat or poultry and is issued a fine. The yearly contract fee remains intact, and the fee is paid by the processors. The yearly contract fee must remain intact; otherwise, processors may find it economical to contaminate their product by rodents to avoid the service fee.

The use of contracts with other service providers can reduce avoidance activity and the original crime. The contracts can be set up with accountants, lawyers, and financial advisors. The contracts would resemble the pest control example by increasing the liability of the service provider. Rules and regulations already exist for accountants and lawyers, so the regulations associated fine's amount would be increased to limit avoidance activity. The increase in the fine's amount will also increase the amount of money a service provider will charge to processors to participate in avoidance activities.

The service providers fine and/or restitution cost would have to be greater than the sum of the contract fee and the economic benefit their customer may receive for their participation in the original crime and avoidance activity. The sale of uninspected meat and tax evasion of an " $x$ " amount would be an example of the economic benefit a service provider may receive from illegal activity. The service provider and processor would have no economic gain from avoidance activity. The amount of contract fees that will be transferred to consumers is undetermined at this point. The marginal cost to processors for the contracts could be greater for small plants compared to large plants as in the example of the findings by Ollinger et al. (2004) presented earlier.

\section{Conclusion}

The sale of meat and poultry contains asymmetric information dealing with food safety. Since pathogens in most cases are invisible, consumers lack information on the safety of meat and poultry. Government interaction through the Food Safety and Inspection Service (FSIS) in the meat and poultry industry is necessary to regulate the safety of meat and poultry products. Inevitably, any rules in society are likely to include violators. In the meat and poultry industry, violators of the regulations may see economic benefit to do so. The cost of perfectly safe food is far too great for the industry to bear. The marginal gain in revenue from violating a regulation may be greater than the marginal cost. Violators of rules may resort to sophisticated means to avoid detection of the original violations. The means used to avoid detection may be legal or illegal in and of themselves. Effective regulation of avoidance activities will lead to lower violations of the original crime. Such regulations may be ex-ante or ex-post. This paper discusses potential effectiveness of ex-ante or ex-post regulations on avoidance activities of food safety regulations in the meat and poultry industry. The use of ex-ante measures such as contracting external service providers coupled with the threat of ex-post punishment on service providers would potentially decrease the number of avoidance activities and their associated original crime in the meat and poultry industry. Utilizing such an ex-ante measure would reduce the amount of cases such as the LaGrou Distribution System example and the Kingsville Hog market example. The cases mentioned are examples where the crime was detected; however there may be multiple cases where the crime goes undetected. The use of ex-ante measures on service providers would likely reduce the total number of processors noncomplying with food safety regulations. To conclude, the paper is intended to raise the awareness of the existence of the problem of avoidance of food safety regulations in meat packing industry, its potential legal and economic consequences, and potential for further legal actions, ex-ante and ex-post, against the violators.

\section{REFERENCES}

Antle, J. M. (1996). Efficient food safety regulation in the food manufacturing sector. American Journal of Agricultural Economics, 78, 1242-1247. doi:10.2307/1243500

Antle, J. M. (2000). No such thing as a free safe lunch: The cost of food safety regulations in the meat industry. American Journal of Agricultural Economics, 82, 96-106. doi:10.1111/0002-9092.00027

Cho, B. H., \& Hooker, N. H. (2004). The opportunity cost of food safety regulation. Agricultural, Environmental, and Development Economics Working Paper. Columbus, OH: Ohio State University.

Federal Meat Inspection Act (2012). Title 21-Food and drugs; Chapter 12-Meat inspection; Subchapter I-Inspection requirements; Adulteration and misbranding.

http://www.fsis.usda.gov/Regulations_\&_Policies/fmia/index.asp

Food Processing (2002). Crimes and misdemeanors, recalls can mean jail time.

http://www.jenner.com/files/tbl_s20Publications\%5CRelatedDocum entsPDFs1252\%5C386\%5CCrimes\%20and\%20Misdemeanors.pdf

Hause, J. H. (2006). Offsetting behavior and the benefits of safety regulations. Economic Inquiry, 44, 689-698.

http://www.fsis.usda.gov/Fsis_Recalls/index.asp

http://www.usdoj.gov/usao/mow/news2007/anstine.sen.htm

Keener, K. (2007). A pest control program. Safe food guidelines for small meat and poultry processors. Purdue Extension. 


\section{MILJKOVIC, D. BRAUN}

Miljkovic, D., Nganje, W., \& Onyango, B. (2009). Offsetting behavior and the benefits of the food safety regulation. Journal of Food Safety, 29, 49-58. doi:10.1111/j.1745-4565.2008.00138.x

Muth, M. K., Karns, S. A. Wohlgenant, M. K., \& Anderson, D. W. (2002). Exit of meat slaughter plants during implementation of the PR/HACCP regulations. Journal of Agricultural and Resource Economics, 27, 187-203. doi:10.1111/j.1467-9353.2007.00374.X

Muth, M. K., Wohlgenant, M. K., \& Karns, S. A. (2007). Did the pathogen reduction and hazard analysis and critical control points regulation cause slaughter plants to exit? Review of Agricultural Economics, 29, 596-611.

Nganje, W., \& Mazzocco, M. (2000). Economic efficiency analysis of HACCP in the US red meat industry. In L. Unnevehr (Ed.), The economics of HACCP: Costs and benefits (pp. 241-265). St. Paul, MN: Eagan Press.

Nganje, W., Miljkovic, D., Voica, D., \& Onyango, B. (2007). Offsetting behavior and the benefits of food safety policies. Agribusiness and Applied Economics Report. Fargo: North Dakota State University.

Nussim, J., \& Tabbach, A. D. (2008). Controlling avoidance: Ex-ante regulation versus ex-post punishment. Review of Law \& Economics, 4, 45-63.

Ollinger, M., \& Moore, D. L. (2008). The economic forces driving food safety quality in meat and poultry. Review of Agricultural Economics,
30, 289-310.

Ollinger, M., Moore, D., \& Chandran, R. (2004). Meat and poultry plants' food safety investments: Survey findings. Washington, DC: US Department of Agriculture, Economic Research Service, Technical Bulletin. doi:10.1111/j.1467-9353.2008.00405.x

Peltzman, S. (1975). The effects of automobile safety regulation. Journal of Political Economy, 83, 677-725. doi:10.1086/260352

Pindyck, R. S., \& Rubinfeld, D. L. (1992). Microeconomics (2nd ed.). New York City: Macmillan Publishing Company.

Rawson, J. M. (2003). Meat and poultry inspection issues. CRS Report for Cogress.

http://digital.library.unt.edu/govdocs/crs/permalink/meta-crs-4682:1.

Sinclair, U. (2006). The jungle. New York: Doubleday, Page \& Company Publishers.

United States Census Bureau, 2002 and 2007.

USDA (1996). The final rule on pathogen reduction and hazard analysis and critical control point haccp systems. http://www.fsis.usda.gov/OA/background/finalrul.htm

USDA (2007). Agency history. http://www.fsis.usda.gov/about_FSIS/Agency_History/index.asp United States of America vs. LaGrou Distribution Systems, Incorporated. United States Court of Appeals for the Seventh District Court. Decided 20 October 2006 